Agro-Science Journal of Tropical Agriculture, Food, Environment and Extension Volume 17 Number 1 (January 2018) pp. $57-62$

ISSN 1119-7455

\title{
ECONOMIC VIABILITY OF OKRA (Abelmoschus esculentus) PRODUCTION IN IKA SOUTH AND NORTH EAST LOCAL GOVERNMENT AREAS OF DELTA STATE, NIGERIA
}

\author{
${ }^{* 1}$ Ekunwe P.A., ${ }^{2}$ Alufohai G. and ${ }^{2}$ Adolue C.F. \\ ${ }^{1}$ Department of Agricultural Economics \& Extension, Faculty of Agriculture, \\ University of Port Harcourt, Nigeria \\ ${ }^{2}$ Department of Agricultural Economics \& Extension Services, Faculty of Agriculture, \\ University of Benin, Nigeria \\ *Corresponding author's email: peter.ekunwe@uniport.edu.ng
}

\begin{abstract}
This study examined the economic viability of okra (production in Ika South and North East Local Government Areas of Delta State. The specific objectives of the study were to describe the socio-economic characteristics of the okra farmers, assess the profitability and viability of okra production and identify the constraints faced by okra farmers in the study area. Data were obtained from 113 okra farmers selected using multi-stage sampling procedure through the use of structured questionnaire and interview schedules. Data obtained were analysed using descriptive statistics and budgetary technique. Results showed that 51.3\% of the okra farmers were females and $90.3 \%$ were married with a mean age of 47 years and mean farming experience of 20 years. The average household size was 5 persons while the mean farm size was 2.03 hectares. The total revenue of the okra farmers was \$235,642.161/ha while the total variable cost was $\$ 76,022.24 /$ hagiving a gross margin of $\$ 159,619.92 / h a$. The total fixed cost was $\$ 2,735.11 /$ ha resulting in a net return of $\$ 156,884.81 / \mathrm{ha}$. The benefit-cost ratio of 2.99 and return on investment of 2.03 indicating that okra production in the study area was viable and profitable. The major problems identified by the okra farmers were difficulty getting funds, bad access roads to farms, difficulty in controlling weeds and pests and diseases. The study concluded that okra farming is profitable in the study area and as such efforts should be made by government to encourage farmers to invest in okra production and young people should be encourage into okra production in the study area.
\end{abstract}

Key words: benefit-cost ratio, economic viability, okra production, return on investment, gross margin

\section{INTRODUCTION}

Vegetables are important protective food for the maintenance of health and prevention of diseases. They contain valuable food ingredients, which can be successfully utilized to build up and repair the body (Bakhru, 2003; Edet and Etim, 2007). In most countries of the world, vegetable are among the staple food components whose production has continued to increase (Udoh and Akpan, 2007). According to Kebede and Gan (1999), the main sources of farm income for small and limited resource farmers are basically arable crop production, vegetables and non-vegetable crops. Its importance has long been recognized the world over (Ndaeyov et al., 2007). Okra is the most important fruit vegetable crop and a source of calorie $(4550 \mathrm{kCal} / \mathrm{kg})$ for human consumption. It ranks first before other vegetable crops (Babatunde et al., 2007). It is one of the most commonly grown vegetable crops in the tropics (Gibbon \&Pain, 1985). Okra cultivation and production has been widely practiced because of its importance to the economy and can be found in almost every market in Africa. Varieties vary by plant height, size of fruit, colour, early or late maturing etc. namely white velvet, green velvet, long pod, lady finger, dwarf green pods (Udoh et al., 2005). According to the same authors, okra is grown generally in the tropics particularly in tropical Asia, East, central and West Africa as well as the Caribbean, et al. (2005) reported that okra is consumed throughout Nigeria. According to Central Bank of Nigeria (1996), the average growth rate of vegetable crop including okra produced in Nigeria between 1989 and 1993 was $14.0 \%$ compared to $6.4 \%$ of cassava, $18 \%$ for palm oil and $3.8 \%$ for maize. Fresh okra fruits have been reported to be a good source of vitamins, minerals and plant proteins (Eke et al., 2005). Despite the numerous uses of okra in Nigeria, its continuous demand and the various initiatives aimed at improving the production of other vegetables, very little effort is observed to have been made to increase its production. Okra is observed to be treated as a minor crop by most farmers and the 
importance given to crops like yam, cassava or maize production is not observed to be given to okra production. Is it that farmers do not realise that there could be enough income from okra production? Or is it that okra production is not profitable or viable? Numerous research on okra production, marketing, processing and utilization has been carried out in the past in several areas across Nigeria. (Ngbede et al., 2012; Nwaobiala and Ogbonna 2014: Law-Ogbomo et al., 2013) however very few works are available especially in Ika South and Ika North East LGAs with respect to economic viability of Okra production. It is against this backdrop that this study sought to address the following objective which are to describe the socioeconomic characteristics of the okra farmers, estimate the costs and return in okra production, hence the profit; assess the viability of okra production as an enterprise and identify the constraints faced by okra farmers in okra production.

\section{MATERIALS AND METHODS}

\section{Area of study}

The study was conducted in Delta State, Nigeria. The state is located in the southern part of Nigeria in the rainforest zone. It is situated between longitudes $5^{\circ}$ and $6^{\circ} 45^{1}$ East of the Greenwich meridian and latitudes $5^{\circ}$ and $6^{\circ} 30^{1}$ North of the Equator and covers a land area of about 17,698 $\mathrm{km}^{2}$. It is bounded in the North and West by Edo State, East by Anambra, Imo and Rivers States. South east by Bayelsa State and on the southern flank is the Bight of Benin which covers about $160 \mathrm{~km}$ of the states coastline (Giroh et al.,2013) Delta State has 25 Local Government Areas the capital is Asaba. It has a projected population of about 4,675, 526 people (National Bureau of Statistics 2012) and about $45 \%$ of this population is adolescent and youths. The vast majority of this population is involved in agriculture, they are mainly peasant farmers, fishermen and traders, variety of plants thrive in the area. The annual precipitation is between 1,500 and $3,000 \mathrm{~mm}$ (Giroh et al., 2013). The climate is characterized by the wet and dry seasons. The dry season lasts between November and March, while the wet season lasts between April and October. The temperature averages about $25^{\circ} \mathrm{C}$ in the wet season and $28^{\circ} \mathrm{Cin}$ the dry season. This study specifically, was conducted in Ika North East and Ika south local government areas of Delta State. Ika North East and Ika South Local Government Areas, occupy a land area of 117.45 square kilometres with a total population of about 364,515 people (National Bureau of Statistics 2012). The soil type found in both areas is predominantly clay-loam thus, it makes the region favorable for crop production and the major vegetable crop produced include pumpkin and okra; other crops produced in the two area are yam, cassava, and maize.

\section{Sampling Technique}

The population of the study comprised and Ika North East LGA in Delta State. Multi-stage sampling procedure was used in drawing out the sample for this study. First purposive sampling was employed in selecting 15 villages that are predominant in okra production within the study area. Thus, 8 villages were selected from Ika North East Local government, the villages are: Umunede, Obior, Mbiri, Ekuoma, Akumazi, Owa-Alizomor, Otolopkp, Owere Olubor and 7 villages were selected from Ika South Local Government area they are: Omumu, Abavo, Agbor, Aliokpe, Alihagu, Ekwueze and Oyoko. Secondly, snow ball sampling procedure was used to select the respondents since there was no list of okra farmers in the study areas and so, 11 respondents were selected from Umunede, 8 from Obior, 2 from Mbiri, 13 from Ekuoma, 16 from Akumazi, 4 from Owa-Alizomor, 5 from Otolokpo and 2 from Owere- Olubor making a total of 61 respondents from Ika North East Local Government area while, 5 respondents were selecfted from Omumu, 20 from Abavo, 13 from Agbor, 7 from Ali-okpe, 2 from Alihagu, 2 from Ekwueze and 3 from Oyoko making a total of 52 respondents from Ika South Local Government area. A total of 113 respondents were selected from the study areas.

\section{Sources of Data and Data Collection}

Both primary and secondary data were used for the study. The primary data were obtained using the survey method, with the administration of wellstructured questionnaire, assisted with interview schedule for the non-literate respondents. The questionnaire was designed to capture relevant data for this study. The secondary data were sourced from relevant research institutes, publications, journals and internet and were used for the literature and discussion of results.

\section{Analytical Technique}

Data collected from the respondents were analysed using statistical tools, such as descriptive statistics (frequency counts, percentages and means) and budgetary model. A five point Likert type scale was used to identify and measured the constraints faced by okra farmers in the study area.

\section{Budgetary Model}

This involves the estimation of total revenue and cost of production. The gross margin of an enterprise is the difference between the total value of production (total revenue) and total variable cost. Mathematically it can be expressed as:

$$
\mathrm{GM}=\mathrm{TR}-\mathrm{TVC}
$$


where GM is gross margin, TR is total revenue (unit price of output $\times$ Quantity of output), and TVC is total variable cost (sum of unit price of each variable input $\times$ quantity of each variable input).

The net return was represented mathematically as:

$$
\mathrm{NR}=\mathrm{GM}-\mathrm{TFC}
$$

where NR is net return, TFC is total fixed cost derived by depreciating fixed assets.

The depreciation was done using the straight line method as shown below:

$$
\text { Depreciation }=\frac{\mathrm{C}-\mathrm{S}}{\mathrm{N}}
$$

where $\mathrm{C}$ is cost of acquiring the fixed asset, $\mathrm{S}$ is salvage value of the fixed asset, $\mathrm{N}$ is expected life span of the fixed asset.

Benefit-cost Ratio (BCR): This is the ratio of total discounted revenue and total discounted cost. Mathematically it is given as:

$$
\begin{aligned}
\text { BCR } & =\frac{\text { Present Value of Total Revenue }}{\text { Present Value of Total cost }} \\
\mathrm{BCR} & =\frac{\frac{\Sigma \mathrm{x}_{\mathrm{i}}}{(1-\mathrm{r})^{\mathrm{n}}}}{\frac{\Sigma \mathrm{C}_{\mathrm{i}}}{(1-\mathrm{r})^{\mathrm{n}}}}
\end{aligned}
$$

where $\frac{\Sigma \mathrm{X}_{\mathrm{i}}}{(1-\mathrm{r})^{\mathrm{n}}}$ is present value of stream of income, and $\frac{\Sigma C_{i}}{(1-r)^{n}}$ is present value of stream of invested amount. The decision rule goes thus:

$\mathrm{BCR}>1 \ldots \ldots \ldots \ldots . . . .$. the business is viable;

$\mathrm{BCR}=1 \ldots \ldots \ldots \ldots \ldots . . . . .$. break-even point;

$\mathrm{BCR}<1$................. the business is not viable.

However, the figures for this project were not discounted because they were cross-sectional data.

Return on investment (ROI) was calculated using the formula:

$$
\text { ROI }=\text { Net Return/ Total Cost }
$$

Likert scale: A Likert scale is a widely used question format that asks respondents to numerically rate whether they agree or disagree with a particular statement (Kotler and Keller, 1997). The mean Likert scale point served as a benchmark on which the constraints were judged. The mean was obtained by the given formula:

$$
\text { Mean }=\sum_{n}^{i} X_{i} \frac{5+4+3+2+1}{5}=3
$$

where $\mathrm{i}=1,2,3 \ldots \mathrm{n}$;

$\mathrm{n}=$ Number of occurrence;

$\mathrm{X}=$ the assigned value of constraints (i.e., very serious $=5$, serious $=4$, indifferent $=3$, moderate serious $=2$, not serious $=1$ ). The average score for each constraint was compared with the benchmark three (3). Any average score above 3 signified a serious constraint while those below 3 were considered not serious.

\section{RESULTS AND DISCUSSION}

Socio-economic characteristics of okra farmers

The socio-economic characteristics of okra farmers in the study area is presented in Table 1 . The table shows that most of the okra farmers are females $(51.3 \%)$, indicating that okra farming is dominated by women in the study areas. This results agrees with the findings of Nwaobiala and Ogbonna (2014) who report that $51 \%$ of Okra farmers in Aninri Local Government Area of Enugu State, Nigeria were females. Majority $(80.5 \%)$ of the Okra farmers fell between the age range of 20-50 years. This result shows that majority of the respondents were in their active and productive years. This finding is in agreement with Moyib et al. (2013), Girei et al. (2014) and Onubuogu et al. (2014) that majority of farmers were within the age range of 41-50 years and were still in their active age and may be more receptive to innovation. According to Yusuf, Lategan and Ayindie (2013), age plays a significant role in farming as it determines the farmers' ability to carry out tedious and rigorous work as defined by some activities in okra cultivation. Table 1 also reveals that $90.3 \%$ of the farmers were married with a mean household size of 5 persons. This result indicated that majority of the respondents were married and with average household size. This finding supports the result of Onubuogu and Onyeneke (2012) and Esiobu and Onubuogu (2014), who reported that large and average household size compliments labour to enhance production and reduce cost of hired labour. The educational status of okra farmers as presented in Table 1 shows that a majority $(38.9 \%)$ of the farmers had secondary education. While primary education, tertiary education and those with no formal education were $17.7 \%, 26.5 \%$, and $16.9 \%$ respectively. The result implies that approximately $83.1 \%$ of the respondents had trainings in formal educational institutions which in no doubt increases their literacy level. It is expected that a higher level of education will contribute significantly to decision making of a farmer and the ability to adopt new technology and innovations. The table also shows that $23.1 \%$ of the farmers had secondary occupation ranging from teaching, trading, civil service, fishing and some were students. The result as presented in Table 1 also shows that the mean farming experience was 20 years which implies that the Okra farmers in the study area were quite experienced and knowledgeable in okra production. These results are in consonance with the findings of Nwaobiala and Ogbonna (2014) who report that okra farmers had over 20 years farming experience. The mean farm size was 2.03 hectares, indicating that the okra farmers are small scale. These results indicated that the respondents were small scale farmers as usually characterized with majority of the farmers in Nigeria. 
Table 1: Socio-economics Characteristics of Okra Farmers

\begin{tabular}{|c|c|c|c|}
\hline Variables & $\begin{array}{l}\text { Frequency } \\
(\mathrm{n}=113)\end{array}$ & Percentage & Mean \\
\hline Gender: Male Female & 5558 & 48.7 & 51.3 \\
\hline Age: & 17 & 15.1 & 47 years \\
\hline Below 20 & 20 & 17.6 & \\
\hline $21-30$ & 33 & 29.2 & \\
\hline $31-40$ & 38 & 33.7 & \\
\hline \multirow{2}{*}{\multicolumn{4}{|c|}{51 and Above }} \\
\hline & & & \\
\hline Marital status: & 8 & 7 & \\
\hline Single & 102 & 90.3 & \\
\hline Married & 2 & 1.8 & \\
\hline Divorced & 1 & 0.9 & \\
\hline \multicolumn{4}{|l|}{ Widow/widower } \\
\hline Household size: & 21 & 18.6 & 5 persons \\
\hline $1-3$ persons & 64 & 56.7 & \\
\hline 4-6 persons & 15 & 13.3 & \\
\hline 7-9 persons & 13 & 11.4 & \\
\hline \multicolumn{4}{|l|}{ Above 8 persons } \\
\hline Level of education: & 19 & 16.9 & \\
\hline No formal education & 20 & 17.7 & \\
\hline Primary education & 44 & 38.9 & \\
\hline Secondary education & 30 & 26.5 & \\
\hline \multicolumn{4}{|l|}{ Tertiary education } \\
\hline Major occupation: & 87 & 76.9 & \\
\hline Farming & 1 & 0.9 & \\
\hline Civil service & 8 & 7.1 & \\
\hline Teaching & 13 & 11.5 & \\
\hline Trading & 2 & 1.8 & \\
\hline Student & 2 & 1.8 & \\
\hline \multicolumn{4}{|l|}{ Fishing } \\
\hline Farming experience: & 29 & 28.4 & 20 years \\
\hline $1-10$ years & 6 & 43.4 & \\
\hline $11-20$ years & 22 & 19.0 & \\
\hline $21-30$ years & 16 & 14.2 & \\
\hline \multicolumn{4}{|l|}{ Above 30} \\
\hline Farm size: & 7 & 6.2 & 2.03 hectares \\
\hline Less than 1 hectare & 42 & 37.2 & \\
\hline 1-2 hectares & 37 & 32.7 & \\
\hline 3-4 hectares & 27 & 23.9 & \\
\hline Above 4 hectares & & & \\
\hline
\end{tabular}

Source: Field Survey, 2016

\section{Costs and Return in Okra production}

The result of the costs and return analysis is presented in Table 2. The result shows that the total cost variable was estimated to be N76,121.19/ha annually while the total fixed cost was $\$ 2735.11 /$ ha per annum, amounting to a total cost of production of $\$ 78,756.52$ /ha per annum. The bulk of the total cost was spent on labour $(40.5 \%)$ and fertilizer $(23.20 \%)$. The total revenue was valued at $\$ 235,642.161 /$ ha per annum. This gave a gross margin 159,619.92/ha per annum and a net profit of $\$ 156,884.81 /$ ha per annum indicating that Okra production was profitable. The benefit-cost ratio (BCR) gave a value of 2.99 which means that okra production business is viable in the study area. The calculated return on investment (ROI) was 2.03 which means that every 1 invested returns about N2.03 was realized. This result agrees with the findings of Edet and Etim (2010) who reported that okra production was profitable in Ivo Local Government Area of Ebonyi State, Nigeria.
Table 2: Costs and return analysis for okra production per hectare

\begin{tabular}{lll} 
production per hectare & & \\
\hline Items & Amount $(\mathrm{N})$ /ha & Percentage \\
\hline Revenue: & & \\
Sale of Okra $(\mathrm{Q} \times \mathrm{Py})$ & $235,642.161$ & \\
Variable Cost: & & \\
Planting material & $7,702.54$ & \\
(Seeds) 9.78 & & 23.20 \\
Fertilizer & $18,261.10$ & 6.02 \\
Herbicide & $4,738.30$ & 40.5 \\
Labour & $31,903.47$ & 8.25 \\
Transportation & $6,500.00$ & 8.78 \\
Rent on Land & $6,916.83$ & \\
Total Variable Cost & $76,022.24$ & \\
Gross Margin & $159,619.92$ & 3.47 \\
Fixed Cost: & & \\
Depreciation of tools & $2,735.11$ & \\
and equipment & & \\
Total Fixed Cost & $2,735.11$ & \\
Total Cost & $78,757.35$ & \\
Profit/Net Returns & $156,884.81$ & \\
Benefit-cost ratio & 2.99 & \\
Return on investment & 2.03 & \\
\hline Source: Field Survey, 2016. & \\
\end{tabular}




\section{Constraints faced by Okra farmers}

Table 3 shows the various problems in order of seriousness faced by the okra farmers in the study area with their respective mean score obtained from the Likert type scale. Comparing each mean with the Liker type scale benchmark of 3; poor access roads with a mean score of 4.19 was considered most serious by the okra farmers followed by difficulty in getting funds with a mean score of 4.09. Problem of pests and diseases had a mean score of 3.71 followed by problem of weed control with a mean score of 3.50 ; problem of little rain had a mean score of 2.42. Difficulty getting land was also a problem with a mean score of 2.12 , difficulty in finding agrochemicals had a mean score of 1.91 and difficulty in finding fertilizer had a mean of 1.79 while difficulty in finding labour was considered least serious with a mean score of 1.4. This result indicated that despite the fact that okra production is a profitable venture several constraints are still encountered by the farmers in the study area. This results agrees with the findings of Edet and Etim (2010) who identified similar problems among okra farmer in their study.

\section{CONCLUSION AND RECOMMENDATIONS}

The study shows that Okra production in Ika North East and South Local Government Areas of Delta State was a profitable and viable venture. The study therefore recommends that young people should be encourage by government into okra production in the study area as the average age of the farmers surveyed showed that they were relatively advance in age. Also, farmers should form themselves into cooperative societies so as to solve the problem associate with getting fund to carry out their farming activity. With respect to diseases and pest control, research institutes should collaborate with okra farmers in addressing the issue. Moreover, access to farm land should be given more attention through community effort and government intervention.

\section{REFERENCES}

Babatunde R.O., Omotesho O.A. and Sholotan O.S. (2007). Socio-economic characteristics and food security Status of harming Household in Kwara State, North-Central Nigeria. Pakistan Jour. of Nutri., 6 (1), 16

Bakhru H.K. (2003). Foods that heal. The natural way to good health. Orient Paperbacks, Delhi, pp 82-90

Central Bank of Nigeria (CBN) (1996) Annual report and statement of account, Nigeria

Edet G.E. and Etim N.A. (2007) Gender role in fluted pumpkin (Telferia occidentalis) production in Akwa Ibom State. Proceedings of the $41^{\text {st }}$ annual conference of the agricultural society of Nigeria (ASN) held at Zaria, $22^{\text {nd }}-26^{\text {th }}$ October, pp 612615
Edet G.E. and Etim N.A. (2010). Economic analysis of okra production: A case of Ivo Local Government Area of Ebonyi State, Nigeria. Nig. Jour. of Agric., Food and Env., 6 (1\&2), 99-103

Eke K.A., Essien B.A. and Ogbu J.U. (2008) Determination of optimum planting time of okra (Abelmoschus esculentus) Cultivars in the derived savannah. Proceedings of the $42^{\text {nd }}$ Annual conference of agricultural society of Nigeria (ASN). October $19^{\text {th }}$ to $23^{\text {rd }}$ in Ebonyi State University, pp 242-245

Esiobu N.S. and Onubuogu G.C. (2014). Determinant of income from pineapple production in Imo State, Nigeria. An econometric model approach Jour. of Econ. and Sust.Dev.5 (22), 122-132

Federal Office of Statistics (FOS) (1985). Federal republic of Nigeria, National Integrated Survey of Household (N.I.S.H). Lagos, Nigeria: The Nigeria Household 1983/84

Gibbon D. and Pain A. (1985). Crops of the drier regions of the tropics. International tropical agriculture science. Longman London. Pp. 137

Girei A.A., Dire B., Yuguda R.M. and Salihu M. (2014) Analysis of productivity and technical efficiency of cassava production in Ardo-Kola and Gassol Local Government Areas of Taraba State, Nigeria. Agric. Forest. and Fish, 3 (1), 1-5

Giroh D.Y., Adebayo E.F. and Jongur A.A.U. (2013) Analysis of labour productivity and constraints of rubber latex exploitation among smallholder rubber farmers in the Niger Delta region of Nigeria. Global Jour. of Agric. Research, 1 (3), 16-126

Katung M.D. and Kashina B.D. (2005) Time of partial defoliation and gas effect on growth indices and yield of okra (Abelmoschus esculentus) (L) Moench. Proceedings of the $39^{\text {th }}$ annual conference of the agricultural society of Nigeria (ASN) held at Benin, $9^{\text {th }}-13^{\text {th }}$ October, pp 210-213

Kebede E. and Gan J. (1999). The economic potential of vegetable production for limited resource farmers in South Central Alabama. Jour. of Agribus., 17 (1), 63-75

Law-Ogbomo K.E., Osaigbovo A.U. and Ewansiha S.U. (2013). Responses of okra (Abelmoscus Esculentus) to various periods of weed interference in a humid tropical environment. Inter. Jour. ofAgric. and Rural Dev., 16 (1), 1368-1371

Moyib F.R, Akinwumi J.A. and Okoruwa V. (2013). Resource-use efficiency of female cassava farmers in rain-forest zone of Ogun State; Jour. of Agric. Biodiversity Resource, 2 (2), 17-23

National Bureau of Statistics (2012). Annual abstract of statistics 2012. Federal republic of Nigeria

Ndaeyo N.U., Harry G.I. and Idongesit W.E. (2007). Growth of Celosica argentea L. as influenced by complementary use of organic and inorganic fertilizers. Proceedings of the $41^{\mathrm{st}}$ annual conference of Agricultural Society of Nigeria (ASN) at Samaru, Zaria from 22nd - 26th October, pp 62-72

Ngbede S.O., Ibekwe H.N., Okpara S.C., Onyegbuke U.N. and Adejumo I. (2012). An overview of okra production, processing, marketing, utilization and constraints in Ayaragu in Ivo Local Government Area of Ebonyi State, Nigeria. Greener Jour. of Agric. Sci, 4 (4), 136-143 
Nwaobiala C.U., and Ogbonna M.O., (2014) Adoption determinants and profitability analysis of okra farming in Aninri Local Government Area of Enugu State, Nigeria. Discourse Jour. of Agric. and Food Sci., 2 (1), 1-10

Onubuogu G.C. Esiobu; N.S. Nwosu, C.S and Okereke, C.N. (2014). Resource-use efficiency of smallholder cassava farmers in Owerri agricultural zone, Imo State, Nigeria Jour. of Agric. Sci., 4 (6), 306-318

Onubuogu G.C and Onyeneke R.U. (2012). Market orientation of root and tuber crops production in Imo State, Nigeria, Agric. Sci. and Res. Jour., 2 (5), 206- 216
Udoh D.J. Ndon B.A. Asuquo P.E. and Ndaeyo N.U. (2005). Crop production techniques for the tropics Concept Publisher, Lagos, Nigeria, pp 223-247

Udoh E.J. and Akpan S.B. (2007): Measuring Technical Efficiency of Waterleaf (Talinum triangulare) Production in Akwa Ibom State, Nigeria. AmericaEurasian Jour. of Agric. and Env. Sci., 2 (5), 578

Yusuf S.F.G. Lategan F.S. and Masika P.J. (2014). Characterization of Indigenous Poultry Production Systems in the Nkonkobe Municipality, Eastern Cape Province South Africa. Jour. of Agric. Sci. 5 (1-2), 31-44 